\title{
ON THE EXISTENCE OF NULL COMPLEMENT ANAPHORAIN BRAZILIAN PORTUGUESE
}

Sobre a existência da anáfora do complemento nulo no português brasileiro

Sonia Maria Lazzarini Cyrino*

\section{Introduction}

$\mathrm{H}$

ankamer and Sag (1976) first discussed an interesting and ill-understood process, in which the complement of a predicate is phonologically null, the Null Complement Anaphora (NCA) in their terms:

(1) a. I asked Bill to leave, but he refused

b. Sue was attempting to kiss a gorilla, and Harry didn't approve

c. We needed somebody to carry the oats down to the bin, but nobody volunteered ((56) in Hankamer; Sag, 1976, p. 411)

The NCA occurs not only in English but also Italian and in Spanish, ${ }^{1}$ and the interesting thing about this process is that it is restricted to some predicates

* (UEL/CNPq)

1 And perhaps in French - see note 38 in Cyrino and Reich (2000) and Zribi-Hert (1986), who mention the possibility of occurrence of a kind of ellipsis which seems very similar to NCA, with aspectual verbs and modals. Further study is necessary on French data (see Cyrino, 2003). 
CYRINO, S. M. L. On the existence of Null Complement...

(Zubizarreta, 1982; Radford, 1977; Bosque, 1984; apud Depiante 2000; Brucart 1999). Brucart (1999) lists the predicates with which NCA may occur in Spanish: modals, aspectual verbs, verbs that express predisposition, attitude or purpose, causatives that express permission, collaboration or influence on the attitude of others, and some verbs that govern a prepositional complement. He also states that the NCA is in complementary distribution with the neuter clitic "lo", that is, verbs that allow "lo" do not allow NCA (2) ((92) in Brucart, 1999):

(2) Comenzó a escribir el artículo. Lo comenzó a escribir. *Lo comenzó. '(He) began to write the article. $(\mathrm{He})$ began to write it. (He) began it'

Some examples of NCA in Spanish are in (3) below (Brucart, 1999, p. 2837 2838 ) - they show that the null complement is an infinitive or subjunctive clause, whose content is expressed either in a linguistic antecedent or in the pragmatic context:

(3) a. Luis fue al acto; María, en cambio, no pudo

'Luis went to the act; María, in turn, couldn't (go)'

b. La invitaron a visitar la exposición y rehusó

'(They) invited her to visit the exposition and (she) refuse (to visit the exposition)'

c. Le gusta bailar el charlestón, pero su marido no sabe

'(She) likes to dance the charleston, but her husband doens't know (how to dance the charleston)

d. El chico estudia porque su madre quiere = que estudie] (Bosque, 1984:176).

'The boy studies because his mother wants (him to study)'

In this paper, I will look at Brazilian Portuguese data and discuss the existence of the NCA in this language, based on the analysis proposed for Spanish and Italian in the work of Depiante (2000). 
CYRINO, S. M. L. On the existence of Null Complement...

\section{NCA in Spanish and Italian}

\section{Arguments for NCA as deep anaphor}

Depiante (2000) assumes along with Hankamer and Sag the distinction between deep and surface anaphora and considers the NCA as a deep anaphor in the view of the following tests: a) NCA can have a nonlinguistic antecedent; b) it does not require strict parallelism; c) it exhibits the missing antecedent phenomenon. I will briefly review her tests:

a) The first test presented in Depiante (2000) deals with the availability of a pragmatic antecedent for the NCA, which, according to Hankamer and Sag does not exist for surface ellipsis as VP ellipsis. The examples Depiante gives in Spanish and Italian occur with modals:

(4) [Javier jumps into the icy cold sea]

Juan says: You también puedo ___!

'I also can'

(5) Context: [ Mary is going out to play]

Ana says: Io non posso

'I can't'

b) The strict syntactic parallelism test is also used ${ }^{2}$ to show that NCA is a deep anaphor, since, as Hankamer and Sag argue, only surface anaphors need to be syntactically parallel to their antecedents:

(6) Juan las quiere ver y María también quiere _ ( (2c) in Depiante, 2000, p. 23)

'Juan wants to see them and María also wants (to see them)

2 Perhaps this is not a valid test for deep anaphors as opposed to surface ellipsis in the view of the work of Zocca (2003) for VP ellipsis, in which the author demonstrate how the lack of syntactic parallelism in VP ellipsis such as (i) can be accounted for:

(i) A Maria pagou, mas o João não vai [pagar] (example (19) in Zocca, 2003. p. 15)

Zocca argues that there is syntactic parallelism at one point in the derivation, when the elements are merged, before the operation Agree. 
CYRINO, S. M. L. On the existence of Null Complement...

Here the first conjunct has undergone restructuring (clitic climbing has occurred), but the same does not happen in the second conjunct, that is, there is no strict parallelism and still the sentence is grammatical.

c) The missing antecedent test is used to show that only surface anaphors can contain an element that can serve as antecedents to a pronoun, contrary to what occurs with deep anaphors:

(7) ?? Juan no pudo asesinar a Pablo con un cuchillo pero Pedro sí pudo _ y pro estaba oxidado.

'Juan couldn't kill Pablo with a knife, but Pedro could and (it) was rusty.'

The reason for this is that a deep anaphor never contains an antecedent in any point in the derivation (it does not have internal structure). In (8) we see that there is an overt antecedent for the pronoun and in (9) we have a VP ellipsis structure, which should have internal structure at the ellipsis site.

(8) Juan no pudo asesinar a Pablo con un cuchillo pero Pedro sí pudo asesinar a Pablo con un cuchillo y pro estaba oxidado.

(9) Jack couldn't killl Peter with a knife, but John could, and it was rusty.

\section{Arguments for no internal structure for NCA in Spanish and Italian}

Depiante proposes, also in line with Hankamer and Sag, that there is no internal structure in the null complements in NCA - the reason why they do not allow extraction of elements, and, in Spanish, they do not occur with clitic climbing, long object preposing, and they do not allow change of auxiliary. Her reasoning goes as follows:

a) absence of extraction with NCA

In the extraction test, the argument is that we cannot move a constituent out of a NCA, due to the fact that there is no internal structure in the NCA, so that constituent is never there at any point of the derivation: 
CYRINO, S. M. L. On the existence of Null Complement...

(10) *Juan sabe qué libro Maria quiere/puede leer y Pedro sabe qué revista Ana quiere/puede

'Juan knows which book Maria wants/can read and Pedro knows which magazine Ana wants/can (read)'

Another argument for this position comes from the ungrammaticality of the following sentence:

(11) *This̀ novel, Bill agreed to read and this biography, Peter agreed

According to Depiante, the ungrammaticality of these sentences is explained if we assume there is no internal structure in the null complement, which leaves the wh-phrase and the topicalized NP with no trace to bind. ${ }^{3}$

b) absence of clitic climbing with NCA

An interesting phenomenon happens with some restructuring verbs in Spanish in relation with the NCA: they normally allow clitic climbing (12a), except when there is a NCA (12b). According to Depiante, that fact shows that no restructuring has occurred, due to the lack of internal structure of the complement:

(12) a. Juan quiere ver a Maria. Juan la quiere ver.

'Juan wants to see Maria. Juan wants to see her.'

b. *Juan la quiere ver, y Pedro también la quiere

c) absence of change of auxiliary with NCA

The same can be seen with the change in auxiliary selection in Italian. The auxiliary selection can change with some modals, aspectual and motion verbs in this language, and correlates with clitic climbing and restructuring: the auxiliary is essere when there is restructuring/clitic climbing, and avere otherwise (Rizzi, 1978, apud Depiante, 2000, p. 15):

3 That does not happen, for example, in VP ellipsis, since, according to this line of argument, there is internal structure in that case (Depiante. 2000, p. 28):

(i) Bill knows which book Kris read and Dan knows which journal she did 
CYRINO, S. M. L. On the existence of Null Complement...

(13) a. Maria ha dovuto venirci molte volte

b. Maria c'è dovuta venire molte volte

c. *?Maria ci ha dovuto venire molte volte

This can be correlated with the fact that NCA cannot happen when the auxiliary is essere, which shows restructuring should have happened and the impossibility for it to happen is due to the lack of internal structure of the complement (Depiante, 2000, p. 27): ${ }^{4}$

a. * Mario sarebbe proprio voluto andare a casa e anche Maria sarebbe proprio voluta

'Mario BE really wanted to go home and also Maria BE really wanted'

b. Mario avrebbe proprio voluto andare a casa e anche Maria avrebbe proprio voluto

'Mario HAVE really liked to go home and also Maria HAVE really wanted'.

d) absence of long object preposing

Long object preposing occurs in Spanish and Italian and happens when a direct object moves to the subject position and behaves as a subject, triggering verb agreement. It can happen only when there is a restructuring verb $(15 b)$, in which clitic climbing is possible $(15 \mathrm{c} / \mathrm{d})$ :

(15) a. Si vuole vender queste case a caro prezzo.

'SI wants to sell these houses at a high price'

b. Queste case si vogliono vendere a caro prezzo.

'Theses houses SI want to sell at a high price'

c. Queste case gli si vogliono vendere a caro prezzo.

'These houses to them SI want to sell at a high price'

4 She does not explain why the sentence is grammatical with avere, but this is so probably because in that case the verb volere is not a restructuring verb, and, therefore, allows NCA. I speculate on a different explanation for that fact (see Cyrino, 2003) - difference related to different groups of verbs. 
CYRINO, S. M. L. On the existence of Null Complement...

d. *Queste case si vogliono vendergli a caro prezzo.

'Theses houses SI want to sell them at a high price'

As expected, NCA can not happen with object preposing when there is restructuring (16a) as opposed to when there is no restructuring (16b), hence no object preposing:

a. *Le nuove case si cominceranno a construire e anche i nuovi appartamenti si cominceranno

'The new houses SI start to build and also the new apartments SI start'

b. A Roma si comincerà a construire nuove case ma a Milano non si comincerà presto

'In Roma, SI will start to build new houses but in Milano not SI will star'

Depiante argues that NCA has no internal structure; therefore, the moved object in (16a) will not be able to receive a theta role because there will be no verb to assign it in the second conjunct.

\section{Characteristics of NCA - Depiante's arguments for NCA as a null pro-form}

Considering the characteristics of NCA, Depiante (2000) proposes that it is a null pro-form (which can be interpreted as a property, proposition or a question), similar to "it/lo", occurring in complementary distribution with the overt pronoun. The characteristics of the NCA that justify this position are:

a) it is never interpreted nominally (only as a property or proposition) (17):

(17) a. The teacher told the children that it was time to leave even though they already knew (proposition: "that it was time to leave") 
CYRINO, S. M. L. On the existence of Null Complement...

b. *The children learned the song on Monday but by Friday they no longer knew __ (nominal: "the song")

Compare with (18):

(18) a. *Ana quiere una manzana y María también quiere 'Ana wants an apple and María also wants (an apple)'

b. Ana quiere retirarse temprano y María también quiere 'Ana wants to leave early and María also wants (to leave early)'

b) it has a definite interpretation given by the context (19):

(19) I eat meat and go late to bed, and my brother doesn't approve

Depiante points that this is different from the intransitive use of verbs, like eat: (19) doesn't mean my brother doesn't approve of anything the speaker does, ${ }^{5}$ it means he doesn't approve of the definite fact of the speaker's eating meat and going to bed late.

c) it cannot appear in Antecedent Contained Deletion (ACD) structures (20):

(20) a. * I always eat anything that he volunteers

b. * I refused to do everything that he refused

In contrast, VP ellipsis allows ACD:

(21) a. I always eat anything that he does.

b. I refused to do everything that he did.

d) it does allow sloppy identity readings

(22) John refused to talk to his mother and Peter also refused

5 Although this is like a nominal: "my eating meat and going to bed late" 
CYRINO, S. M. L. On the existence of Null Complement...

This is usually taken as a test for surface anaphors. Since NCA allows the sloppy readings, and is proposed as a deep anaphor, the author is forced to conclude that "sloppy identity is not a necessary or sufficient condition for determining whether a certain element constitutes surface anaphora or not" (Depiante, 2000, p. 34).

Depiante (2000) proposes that NCA is represented in the syntax (contrary to Grimshaw, 1978) as a null pro-form (that can be interpreted as a proposition, a property or a question, and it is analogous to a pronoun, getting its reference from some salient individual in the linguistic or in the non-linguistic context), with no internal structure (therefore, it cannot serve as an antecedent for a pronoun, hence the lack of missing antecedents). It would be the null counterpart of a sentential pro-form as "it" or "so" in English and "lo" in Spanish and Italian" (23):

(23) a. Mary believes that Anne is pregnant but I don't believe it/so ((42a), chapter 3, in Depiante, 2000)

b. Maria cree que Ana está embarazada pero you no lo creo 'Maria believes that Ana is pregnant but I don't believe it' ((43a), chapter 3, in Depiante, 2000)

\section{NCA in BP}

As long as I know, there is no study about NCA in Portuguese. As a first step towards that investigation, in this paper I will assume that the NCA process as studied for English and Spanish can be applied for Portuguese; therefore, I will look at Depiante's description of NCA and see how the BP data fit that characterization.

At first sight, it looks as if BP also has NCA: ${ }^{7}$

6 Although Depiante mentions Italian, she gives no examples which would be comparable to those in (23) here ((42) and (43) in her chapter 3 ) in that language.

7 BP also has null object constructions (i) VP ellipsis (ii) and other kinds of ellipsis (like stripping (iii), gapping (iv), sluicing, (v):

(i) Maria comprou um vestido novo, mas ainda não usou

'Maria bought a new dress, but she still hasn't worn (it)'

(ii) João comprou as maçās no supermercado, mas a Maria não comprou

'João bought the apples in the supermarket, but Maria didn' $t$ '

(iii) a. João deu chocolates para a Maria, e Pedro_também.

'Joāo gave chocolate to Maria, and Peter too' 
CYRINO, S. M. L. On the existence of Null Complement...

(25) a. Eu pedi ao João para partir, mas ele (se) recusou 'I asked John to leave, but he refused'

b. Luis foi ao ato público; Maria, ao contrário, não pôde 'Luis went to the public act; María , in turn, couldn't'

c. Ela gosta de dançar o charleston, mas seu marido não sabe

'She likes to dance the charleston, but her husband doesn't know (how to dance the charleston/ that she likes to dance the charleston)'

d. O menino estuda porque sua mãe quer

'The boy studies because his mother wants (him to study)'

In this paper, however, I question the existence of NCA in BP as it has been classically described in the literature. In what follows I show that the data do not fit the arguments that it is deep anaphora; in fact, we are led to the conclusion that what looks like NCA is a process similar to other surface anaphora.

\section{Deep anaphora status}

a) Argument: surface anaphors only have linguistic antecedents, deep anaphors can have either a pragmatic or a linguistic antecedent

In $\mathrm{BP}$, either a pragmatic (26) or a linguistic antecedent (27) is possible with a "NCA verb":8

(26) [Maria attempts to stuff a 9-inch ball through a 6-inch hoop. Ana notices this and says]:

A: Eu ajudo

'I help

b. João deu chocolates para a Maria e _ flores

'João gave chocolate to Maria and flowers too'

c. João não deu chocolates para a Maria, mas

'João didn't give chocolate to Mary , but to Ana' também. para Ana.

(iv) João gosta de cinema e Pedro de shows musicais.

'João likes cinema and Pedro, musical shows.

(v) João foi para algum lugar no verão, mas não sei aonde 'João went somewhere in the summer, but I don't know where'

8 A "NCA verb" in this paper is a verb which allows a NCA construction. 
CYRINO, S. M. L. On the existence of Null Complement...

(27) Maria insiste em ir ao teatro neste final de semana, mas sua amiga não concorda

'Maria insists on going to the theatre this weekend, but her friend doesn't agree (on going to the theatre)'

However, as pointed out by Chao (1987, p. 119-120), this may not be a conclusive argument for the distinction between deep and surface anaphora, since VP ellipsis, a surface anaphora, may also have a pragmatic antecedent (see also discussion in Chao, 1987):

(28) [In a situation where both participants hesitate in doing something, as jumping into an icy cold swimming pool]:

A: Don't __!

Here, the correct interpretation for the gap is given by the context.

b) Argument: NCA lacks strict parallelism as any deep anaphor.

The problem with this argument is that a surface anaphor such as VP ellipsis also may lack strict parallelism. Therefore, it cannot be conclusive for the status of NCA as a deep anaphor. In fact, as we can see in example (28), in BP, there is no need for strict parallelism in "NCA constructions":

(29) Os pacientes do terceiro andar devem ser removidos ainda que a enfermeira mais forte não consiga

'The patients in the third floor must be removed even if the strongest nurse doesn't manage to (remove them)'

The missing complement is "removê-los" ('remove them'), but the antecedent of the gap is "ser removidos" ('be removed'), a non-parallel structure.

Although Depiante used both arguments to show the deep anaphora status of NCA in Spanish, we saw that they do apply both for deep and surface anaphora as seen above. We cannot rely on them as a correct basis for the distinction. In $\mathrm{BP}$, in fact, they are also inconclusive in relation to the deep anaphora status of the NCA. The next argument, however, is stronger: it shows that BP's NCA-like construction is not, in fact, a deep anaphor: 
CYRINO, S. M. L. On the existence of Null Complement...

c) Argument for missing antecedent: only surface anaphors can contain an element that can serve as antecedents to a pronoun.

In BP, sentences which were considered ungrammatical both in English and in Spanish (see (8-9) above), and thus, argued for the deep anaphora status of the NCA, are grammatical ${ }^{9}$ - see (30). Therefore, it looks like NCA behaves like deep anaphora in BP.

(30) João não pôde assassinar Pedro com uma faca, mas Mário pôde , e ela estava enferrujada.

'João couldn't kill Pedro with a knife, but Mario could, and (it) was rusty'

We may argue that this is a VP ellipsis structure because of the sameness of the verbs (see below), but changing the verb also renders the sentence grammatical (31):

(31) João não pôde assassinar Pedro com uma faca, mas Mário conseguiu __, e ela estava enferrujada.

'João couldn't kill Pedro with a knife, but Mario succeeded and it was rusty'

\section{Lack of internal structure}

The arguments presented in Depiante's work all pointed to the lack of internal structure in NCA constructions. However, the arguments for Spanish ad Italian cannot be used for BP because BP does not have clitic climbing, auxiliary change phenomenon, or long object preposing.

The only test which is possible to be applied in BP is the extraction test, which shows that, in fact, it is possible to extract out of a NCA in BP, contrary to what happens in Spanish:

(32) a. O João sabe que livro a Maria pode ler e o Pedro sabe que revista a Ana pode

9 This happens with VP ellipsis as well (see Zocca, 2003, p. 15). 
CYRINO, S. M. L. On the existence of Null Complement...

'João knows which book Maria can read and Pedro knows which magazine Ana can (read)'

b. Esta novela, o João concordou em ler e este conto o Pedro concordou

'This novel, John agreed to read and this short story Pedro agreed (to read)'

One may argue these are VP ellipsis structures, and therefore, there is internal structure (see Zocca, 2003, p. 16). But if we change the examples (which were translated from Depiante's Spanish examples), we see that it is possible to extract out of a NCA structure in BP:

(33) O João sabe que livro a Maria quis ler e o Pedro sabe que revista a Ana recusou-se

'João knows which book Maria wanted to read and Pedro know which magazine Ana refused (to read)'

(34) Esta novela, o João começou a escrever, mas este conto, ele nunca acabou

'This novel, João began to write, but this short story, he neve finished (to write)'

\section{The characteristics of the NCA}

a) nominal interpretation.

It is difficult to apply this test in BP because of the existence of the null object construction. Both sentences in (35) and (36) (which are the BP correspondents of (17) and (18) above) are grammatical, but we interpret the null object (null "it" - see below):

(35) a. O professor disse para as crianças que era hora de ir embora, mesmo que elas já soubessem __ (proposition: "que era hora de ir embora")

'The teacher told the children that it was time to leave, even though they already knew (propositon: "that it was time to leave") 
CYRINO, S. M. L. On the existence of Null Complement...

b. As crianças aprenderam a música na segunda-feira mas na sexta-feira elas já não sabiam (nominal: "a música")

The children learned the song on Monday but on Friday they already didn't know __ (nominal: 'the song')

(36) a. Ana quer uma maçã e Maria também quer

'Ana wants an apple and María also wants (an apple)'

b. Ana quer ir embora cedo e Maria também quer

'Ana wants to leave early and María also wants (to leave early)'

In (36) in fact, we have a VP ellipsis structure, also possible in BP.

b) definite interpretation given by the context:

Again, this is possible in BP, see (37), but it may be a consequence of the null object construction, since in BP we do not have the occurrence of a neuter clitic "o" ("it") which used to be accepted here - instead, we have a null object, cf. Cyrino (1997).

(37) Eu costumo comer carne e dormir tarde, mas meu irmão não deixa

'I use to eat meat and go to bed late, but my brother doesn't let (me eat meat and go to bed late)'

c) Antecedent Contained Deletion (ACD) structures .

Contrary to what happens in English and Spanish, BP allows ACD in a NCA construction (38), as well as in VP ellipsis constructions (39):

(38) a. Eu sempre digo qualquer coisa que o João se negue (João se nega a dizer algo em particular e eu digo isso) 'I always say anything that João refuses (to say)' (João refuses to say something in particular and I say it)

b. Eu me recuso a fazer qualquer coisa que ele concorde 'I refuse to do anything that he agrees (to do)'

(39) a. Eu me nego a dizer qualquer coisa que ele se negue 'I refuse to say anything that he does'

b. Eu me recuso a fazer qualquer coisa que ele se recuse 'I refuse to do anything that he does' 
CYRINO, S. M. L. On the existence of Null Complement...

d) Sloppy identity readings:

BP, along with English and Spanish, also allows sloppy readings with NCA constructions besides the strict reading, in sentences like:

(40) José se recusou a conversar com sua mãe, mas Pedro concordou 'José refused to talk to his mother, but Pedro agreed (to talk to his mother)'

Since the tests which can be applied in BP show that the NCA has internal structure, we will have to say that it appears not to be a deep anaphor in this language, but it is similar to other surface anaphora - it apparently allows extraction, missing antecedents and occurrence in antecedent-contained deletion structures, besides the availability of sloppy reading.

\section{NCA in BP as reconstruction of the antecedent: evidence from historical data}

I will propose that in BP the null complement in the NCA-like structures in fact has internal structure, which can be thought of as reconstruction of the antecedent, if we assume a copy theory of ellipsis, that is, the ellipsis site contains a syntactic copy of its antecedent that is unpronounced.

The proposal relates the NCA (41) to the null object (42) and draws on the studies in Cyrino (1997) and Cyrino (2003) for null objects in BP and on Cyrino and Matos (2002) for VP ellipsis. In these studies, these processes are instances of reconstruction in LF, licensed by the ASPECT head in BP, as opposed to EP:

(41) a. John asked me to go to the party, and I accepted __. $(-=$ to go to the party)

b. João me pediu para ir à festa, e eu aceitei __. ( $\ldots=$ ir à festa)

(42) a. *John gave me an invitation, and I accepted $\ldots \cdot\left({ }_{-}=\right.$the invitation)

b. João me deu um convite, e eu aceitei $\ldots$. $\left({ }_{-}=0\right.$ convite $)$ 
CYRINO, S. M. L. On the existence of Null Complement...

The main argument for this proposal is that the null object in BP (43a) shows the strict/sloppy ambiguity similar to a (surface) VP ellipsis structure (43b).

a. O João abraça sua mãe, mas a Maria beija 'João hugs his mother, but Maria kisses

b. O João beija sua mãe, e a Maria também beija 'João kisses his mother, and Maria does too'

In one interpretation, we can have the sloppy reading, in which Maria kisses her own mother whereas in the other interpretation, we can have the strict reading, in which she kisses John's mother.

As we saw, one of the arguments presented above for the NCA as surface anaphora in BP is the availability of strict/sloppy identity (44). Therefore, we can extend the reconstruction analysis to this structure (reconstructed sequence in italics):

(44) João ${ }_{i}$ beijou sua amiga, mas Pedro $_{j}$ não quis $\cdot(\ldots=[$ beijar sua $a_{i j}$ amiga])

'John ${ }_{\mathrm{i}}$ kissed his friend but Peter $_{\mathrm{j}}$ didn't want to $\ldots$. $\mathrm{C}_{-}=[$kiss

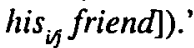

This is also the case (in Cyrino, 1997) for the neuter clitic "o", which would be the spell out of the reconstruction of the antecedent, allowing, therefore, the same reading ambiguity: ${ }^{10}$

(45) João disse que ele ${ }_{i}$ vai ser professor, mas Maria não quis afirmálo. (lo $=\left[\right.$ que ele $_{i}$ vai ser professor /que ela ${ }_{j}$ vai ser professora $]$ ) 'João said that he $e_{i}$ will be a teacher, but Maria didn'want to declare it. (it $=\left[\right.$ that he $_{i}$ is going to be a teacher/ that she ${ }_{j}$ is going to be a teacher])'

The reconstruction is necessary in (45) to account for the interpretation (and agreement) for gender needed in this sentence in BP.

10 These pronouns, which are low in the Referential Hierarchy proposed in Cyrino, Duarte and Kato (2000), would allow reconstruction at LF. 
CYRINO, S. M. L. On the existence of Null Complement...

We saw that, according to Depiante and Brucart, the NCA is in complementary distribution with the pronouns "it" or "lo". But according to the Spanish data, the verbs querer and saber are NCA verbs, but they may have "lo" as a complement (Depiante, 2000, p. 52). So the problem with the "complementary distribution" proposal is that we cannot rely completely on it to identify "NCA verbs".

Therefore, in order to identify NCA in BP based on Spanish, we should rely not only on the classification given by Depiante (2000) and Brucart (1999) but also on the nature of the gap: if it is an infinitive or a subjunctive clause (although this is not done in Depiante's work: she proposes the NCA as a null pro-form interpreted as propositions, properties or questions). For European Portuguese, Matos (2003) proposes that the NCA is the gap corresponding to a propositional complement, the clitic $o$, or the demonstrative pronoun isso ('this'), which, in this context, would denote a given situation, not an entity.

In Spanish, we cannot rely on the complementary distribution of "lo" either. Notice, for example, (3d) repeated here - if there is ellipsis, the interpretation is as given in the gloss:

(46) Le gusta bailar el charlestón, pero su marido no sabe __. $\left({ }_{-}=\right.$ bailar el charlestón)

'(She) likes to dance the charleston, but her husband doesn't know (how to dance the charleston)'

However, if "lo" is used in this sentence (cf. Le gusta bailar el charlestón, pero su marido no lo sabe), the interpretation of the clitic will be the proposition "she likes to dance the charleston"."

In addition, we cannot rely on the complementary distribution of " 0 " in order to identify the NCA in BP because we do not have the neuter clitic anymore - therefore, it is very difficult to distinguish between the verbs which allow it and the verbs that disallow it, in order to point out which are the NCA verbs.

My point in this paper is exactly that: we do not have NCA in BP anymore, at least not as a deep anaphora phenomenon, because the possibility for reconstruction and ellipsis extended to the complements of NCA verbs too. In other words, I propose that there was a reanalysis which extended the ellipsis process of reconstruction at LF to all null complements.

11 Zribi-Hertz (1986) in note 3, chapter XII, distinguishes modal "savoir" (quasi-synonim of "pouvoir"), ex. "savoir jouer du piano" which allows null complements, from "savoir" which governs a objective complement ("savoirquón joue du piano") 
CYRINO, S. M. L. On the existence of Null Complement...

Another piece of evidence in BP for the decline of NCA described as deep anaphora, is the loss of clitic climbing with restructuring verbs, which occurred along the loss of $3^{\text {rd }}$ person clitics in BP. In fact, this loss is also used in Cyrino and Matos (2002) to argue that in BP the ASPECT head licenses VP ellipsis, as opposed to EP.

How did this reanalysis happen? In BP the null object is the result of a diachronic change in which the possibility for the absence of the neuter clitic "o" in some sentences ${ }^{12}$ was extended to all cases in which a clitic would appear with the same kind of antecedent (i.e., a [+especific, - animate] antecedent). ${ }^{13}$

This, of course, demands further investigation, and further data. ${ }^{14}$ But we can see, as a first step in that investigation, that there is variation in the appearance of the clitic "o" which should be allowed with non-NCA verbs in data from the XIX century (47a/b) (taking this verb to be a non-NCA verb on the basis of Spanish and English data):

(47) a. [Assim o pensamos] porque por mais tratos que temos dado ao espirito não encontramos a causa procedimento de Sua Exce. lência, ... (editor's letter to a newspaper, XIXth century, Correio Paulistano, 29/07/1857, in Barbosa \& Lopes, in press, chapter 6, letter 506)

'[Thus (we) think (it)] because even with the great work we have given to the spirit we have not found the cause of the behavior of Your Excellency...'

b. Realmente chamam alguns, alardear probidade, aos que como eu repellem uma offensa, mas [os que assim _ pensam], são sempre alguns polichinellos merins, ... (editor's letter to a newspaper, XIXth century, $O$ Dezenove de Dezembro, in Barbosa \& Lopes, in press, chapter 3, letter 238)

"Actually, some call "to show off honesty" the fact that the

12 A point under investigation is: in which sentences was the clitic "o" absent - with NCA verbs (with infinitives and subjunctive clauses as null complements) or with other verbs (with finite indicative clauses as complements)?

13 The reconstruction proposal accounts for the cases of null object in BP, as in (i) below:

(i) - Está faltando um copo dos novos...

- Se está faltando, é porque você quebrou (Marques Rebelo, Rua Alegre 12,1940)

Here the reconstruction and ellipsis is for a [-specific, -animate] antecedent. See Cyrino (1997) for a detailed analysis.

14 The details of the diachronic change are currently under investigation (cf. Cyrino, 2003) 
CYRINO, S. M. L. On the existence of Null Complement...

ones like me refuse an offense, but [the ones who thus think], are always some little Punchinellos, ...'

\section{Conclusion}

The NCA is a poorly understood phenomenon, which occurs in various languages, invariably related to auxiliary and/or aspectual verbs. There is a restriction on the nature of the null complement as well, but very few accurate descriptions or analysis of the process have been advanced.

In this paper, I have shown that, in order to fully understand both the NCA process and the ellipsis facts about BP, we have to investigate several aspects of the phenomenon, and refine the classification given in Depiante (2000) and Brucart (1999), plus the work recently done on European Portuguese (Matos, 2003), based on the observations of other languages and on the different types of verbs, in order to understand which null complement is the result of the NCA phenomenon and which is the result of other processes.

\section{RESUMO}

A Anáfora do Complemento Nulo (ACN) ocorre em algumas línguas como o espanhol, italiano e inglês (Depiante, 2000; Brucart, 1999), c foi primeiramente estudada por Hankamer e Sag (1976). Certos verbos selecionam a ACN c o conteúdo do complemento nulo está expresso ou em um antecedente lingúístico ou no contexto pragmático. Depiante (2000) propõe que a $\mathrm{ACN}$ é uma "anáfora profunda", mais especificamente uma proforma nula semelhante ao "il" do inglês ou o "lo" do espanhol, sem estrutura interna. Neste trabalho, relaciono seus argumentos e proponho que o português brasileiro (PB) não apresenta a $\mathrm{ACN}$ como classicamente descrita, já que parece não ser uma anáfora profunda nessa língua, mas é semelhante a outras anáforas de superfície - aparentemente permite extração, antecedentes ausentes e a ocorrência de estruturas com apagamento contido no antecedente. Também relaciono a ausência de ACN no PB à ausência de alçamento de clíticos com verbos de reestruturação, a ocorrência de objetos nulos, e a ausência do clítico neutro "o". Proponho que em PB o complemento nulo das estruturas semelhantes a $A C N$ de fato tem estrutura interna, que pode ser pensada como uma reconstrução do antecedente se considerarmos uma teoria de cópia para a elipse, isto é, o local da elipse contém uma cópia sintática de seu antecedente, que não é pronunciada. A 
CYRINO, S. M. L. On the existence of Null Complement...

proposta relaciona a ACN ao objeto nulo, a partir de estudos de Cyrino $(1994 ; 1997)$ e Cyrino e Matos (2002).

Palavras-chave: anáfora do complemento nulo, elipse, português brasileiro.

\section{ABSTRACT}

The Null Complement Anaphora (NCA) occurs in some languages as Spanish, Italian and English (Depiante, 2000; Brucart, 1999), and was first discussed by Hankamer and Sag (1976). Certain verbs select NCA, and the content of the null complement is expressed either in a linguistic antecedent or in the pragmatic context. Depiante (2000) proposes that the NCA is a deep anaphor, more specifically, a null pro-form similar to English "it" or Spanish "lo" with no internal structure. In this paper, I review her arguments, and I propose that Brazilian Portuguese (BP) does not show NCA as it has been classically described, since it appears not to be a deep anaphor in this language, but it is similar to other surface anaphora - it apparently allows extraction, missing antecedents and occurrence in antecedent-contained deletion structures. I also relate the absence of $\mathrm{NCA}$ in BP to the absence of clitic climbing with restructuring verbs, the occurrence of null objects, and the absence of the neuter clitic "o" ("it"). I propose that in BP the null complement in the NCA-like structures in fact has internal structure, which can be thought of as reconstruction of the antecedent, if we assume a copy theory of ellipsis, that is, the ellipsis site contains a syntactic copy of its antecedent that is unpronounced. The proposal relates the NCA to the null object drawing on the studies in Cyrino (1994; 1997) and Cyrino and Matos (2002).

Key-words: null complement anaphora, ellipsis, Brazilian Portuguese

\section{REFERENCES}

BOSQUE, Ignacio. Negación and ellipsis. Estudios de Linguistica, v. 2, p. 171-199, 1984.

BRUCART, Jose Maria. La elipsis. In: BOSQUE, Ignacio; DEMONTE, Violeta (Orgs.). Grammatica descriptiva de la lengua española. Madrid: Espasa Calpe, 1999.

BARBOSA, Afrânio; LOPES, Célia. Crítica, queixumes e bajulaşốs na imprensa do século $X I X$ : cartas de leitores e cartas de redatores. Rio de Janeiro: UFRJ. No prelo.

CYRINO, Sonia Maria Lazzarini. $O$ objeto nulo no português do Brasil: um estudo sintáticodiacrônico. Londrina: UEL, 1997. 
CYRINO, S. M. L. On the existence of Null Complement...

CYRINO, Sonia Maria Lazzarini. Para a história do português brasileiro: investigando a Anáfora do Complemento Nulo, a categoria Aspecto e o Objeto Nulo no português brasileiro. Research project supported by CNPq. 2003.

CYRINO, Sonia Maria Lazzarini; MATOS, Gabriela. VP ellipsis in European and Brazilian Portuguese: a comparative analysis. Journal of Porfuguese Linguistics, v. 1, n. 2, p. 177 $195,2002$.

CYRINO, Sonia Maria Lazzarini; DUARTE, Maria Eugênia Lamoglia; KATO, Mary. Visible subjects and invisible clitics in Brazilian Portuguese. In: KATO, Mary; NEGRÄO, Esmeralda (Orgs.). Brazilian Portuguese and the Null Subject Parameter. Frankfurt am Main: Vervuen, 2000.

CYRINO, Sonia Maria Lazzarini; REICH, Uli. Uma visão integrada do objeto nulo no Português Brasileiro. Romanistiches Jahrbuch, n. 52, p. 360-386, 2002.

DEPIANTE, Marcela. The syntax of deep and surface anaphora: a study of null complement anaphora and stripping/bare argument ellipsis. Connecticut, 2000. Tese (Doutorado) University of Connecticut.

HANKAMER, Jorge; SAG, Ivan. Deep and surface anaphora. Linguistic Inquiry, v. 7, n. 3, p. $391-426,1976$.

MATOS, Gabriela. Construções elípticas. In: MATEUS et al. (Orgs.). Gramática da língua portuguesa. Lisboa: Caminho, 2003.

RADFORD, Andrew. Italian syntax: transformational and relational grammar. Cambridge: Cambridge University Press, 1977.

TORREGO, Esther; URIAGEREKA, Juan. Indicative dependents. Maryland: University of Maryland, 1992. Mimeog.

ZUBIZARRETA, Maria-Luiza. On the relationship of the lexicon to the syntax. Cambridge, 1982. Tese (Doutorado) - MIT.

ZRIBI-HERTZ, Anne. Relations anaphoriques en Fransais: esquisse d'une grammaire générative raisonné de la réfléxivité et de l'ellipse structurale. Paris, 1986. Tese (Doutorado) - University of Paris. 